\title{
Fact-Checking Journalism sebagai Platform Kolaborasi Human and Machine pada Jurnalisme Digital
}

\author{
Mufti Nurlatifah' \\ Program Doktor Ilmu Komunikasi \\ Fakultas Ilmu Sosial dan Ilmu Politik Universitas Indonesia, Jakarta, Indonesia \\ Email:mufti.latifah@gmail.com \\ Irwansyah \\ Departemen Ilmu Komunikasi \\ Fakultas Ilmu Sosial dan Ilmu Politik Universitas Indonesia, Jakarta, Indonesia \\ Email: irwansyahog@ui.ac.id
}

\begin{abstract}
Fact-checking journalism becomes a new trend in journalism studies. The peculiarities of fact-checking journalism are the collaborations which developed beyond boundaries of the editorial room and conventions of journalism. Human and machine disruptions within fact-checking journalism are unavoidably developed into hypermedia organization. Collaboration is built amongst journalist, user, and digital media application in order to describe the whole factual context This paper reviews this phenomenon as main concept of hypermedia organization manifestation in fact-checking journalism.
\end{abstract}

Keywords: digital journalism, fact-checking, hypermedia organization, collaboration

\begin{abstract}
Abstrak: Jurnalisme pemeriksa fakta (fact-checking journalism) menjadi tren baru dalam perkembangan jurnalisme digital. Kekhasan Jurnalisme pemeriksa fakta adalah kolaborasi yang melampaui batasan ruang redaksi dan pakem jurnalisme pada umumnya. Disrupsi manusia dan mesin membuat jurnalisme digital niscaya berkembang menjadi organisasi hipermedia. Kolaborasi terbangun dari jurnalis, pengguna media, serta aplikasi digital untuk membaca konteks faktual secara menyeluruh. Tulisan ini mengulas fenomena jurnalisme pemeriksa fakta sebagai sebagai manifestasi organisasi hipermedia.
\end{abstract}

Kata Kunci: jurnalisme digital, pemeriksa fakta, organisasi hipermedia, kolaborasi

\footnotetext{
${ }^{1}$ Penulis Korespondensi
} 


\section{Pendahuluan}

Fact-Checking explosion merupakan salah satu fenomena yang diprediksi oleh UNESCO (2018) dan Freedom House (2017) sebagai jawaban atas post-truth. Ledakan yang dimaksudkan di sini merujuk pada banyaknya organisasi pemeriksa fakta yang akan berdiri di seluruh dunia, berikut piranti yang menjadi instrumen pengecek faktanya. Prediksi ini terbukti benar dengan jumlah organisasi pemeriksa fakta di seluruh dunia mencapai 114 organisasi di tahun 2017 (Brandtzaeg and Foldstad, 2017). Pada wilayah global, aktivitas ini digawangi oleh Poynter, Google News Initiative, serta Facebook untuk mengkampanyekan pemeriksaan fakta dalam informasi digital.

Di Indonesia, terdapat dua kategori organisasi pemeriksa data sampai saat ini. Kategori pertama adalah organisasi media yang melakukan pemeriksaan fakta dengan menyediakan kanal khusus untuk factchecking journalism. Kategori ini ditemukan pada Tirto, salah satu media daring di Indonesia yang digandeng oleh Facebook sebagai third party fact checking dan telah terakreditasi oleh International Fact Checking Network (IFCN) pada Januari 2018. Selain Tirto, pada 2018, sejumlah media lain di Indonesia juga menyusul tersertifikasi oleh IFCN, yaitu Cek FaktaLiputan 6 (Juli 2018), Tempo.co (Agustus 2018), dan Hoaks atau Fakta-Kompas.com (Oktober 2018). Kategori yang kedua adalah organisasi asosiasi, baik dari media maupun non-media. Di Indonesia, kategori kedua ini ditemukan pada Cekfakta.com yang diinisiasi oleh Masyarakat Anti Fitnah Indonesia (Mafindo), Aliansi Jurnalis Independen (AJI), dan Asosiasi Media Siber Indonesia (AMSI), Google News Initiative serta First Draft.
Pada platfrom jurnalisme, faktualitas dan verifikasi informasi merupakan jantung jurnalisme, pemeriksaan fakta dalam organisasi media menjadi suatu kelaziman. Jurnalis berkomitmen tinggi kepada kebenaran (Kovach \& Rosentiel, 2003: 121) sehingga apapun yang ia sampaikan kepada masyarakat yang mengakses informasi merupakan informasi yang telah terverifikasi. Verifikasi mengandaikan proses jurnalistik yang telah memenuhi penyaringan fakta sehingga menghindari desas-desus, isu, dan pra sangka yang belum tentu kebenarannya (Kovach \& Rosentiel, 2003:87). Pada prinsipnya, verifikasi atas suatu fakta ini dilakukan dengan melakukan pencarian data sebanyakbanyaknya dan mendapatkan sumber berita melalui berbagai macam sumber yang sah. Dua elemen kunci dalam proses verifikasi adalah sumber konten media dan konten media itu sendiri (Brandtzaeg,et.al., 2015).

Pada perkembangannya, pemeriksaan fakta tidak hanya menjadi aktivitas jurnalisme pada platform media digital, terlebih dengan munculnya medium pendukung dan aplikasi digital yang memfasilitasi pemeriksaan fakta secara lebih komprehensif. Aktivitas yang dilakukan oleh sejumlah media digital ini mendorong jurnalisme pemeriksaan fakta berkembang menjadi genre baru dalam jurnalisme digital. Inilah yang menjadi dasar asumsi dalam paparan konseptual di tulisan. Jurnalisme pemeriksa fakta menyajikan informasi dengan menggunakan maksimalisasi fitur digital. Jika dalam jurnalisme digital secara umum penyajian data masih bertumpu pada hiperlink dan multimedia (Pavlik, 2008; Kawamoto, 2003), jurnalisme pemeriksa fakta menerobos lebih banyak lini untuk menghasilkan data yang komprehensif. 
Hiperlink dalam Jurnalisme pemeriksa fakta tidak hanya menautkan berita pada informasi-informasi yang sebelumnya muncul, tapi pada laman-laman yang menjadi materi verifikasi data. Multimedia dalam Jurnalisme pemeriksa fakta tidak hanya berisi infografis, tapi antarmuka (interface) yang mengantarkan pengguna (user) menuju laman-laman lain berisi informasi serupa.

Asumsi yang kedua, aktivitas organisasi media pada Jurnalisme pemeriksa fakta dilakukan di luar kebiasaan jurnalisme pada umumnya. Lazimnya, aktivitas jurnalistik dilakukan di bawah satu bendera perusahaan media karena berkaitan dengan idealisme dan nilai-nilai organisasi media (Schudson, 2001). Namun, kebanyakan aktivitas jurnalisme pemeriksa fakta justru beraktivitas secara kolaboratif dengan organisasi media lainnya atau platform digital tertentu. Tirto dengan Facebook, Cekfakta.com dengan Google, serta Cek Fakta Tempo.co dengan Mafindo merupakan sebagian kecil dari kolaborasi yang muncul dalam jurnalisme pemeriksa fakta. Kerja kolaborasi dalam wilayah digital seperti ini ditemukan pada organisasi hipermedia. Inilah yang menjadi dasar asumsi dalam tulisan ini mengenai jurnalisme pemeriksa fakta sebagai manifestasi organisasi hipermedia.

Asumsi ketiga, jurnalisme pemeriksa data menemukan lahan subur seiring bergeliatnya periode politik. Perkembangan Factcheck.org dan PolitiFact.com di Amerika Serikat beriringan dengan tahun politik di Amerika Serikat (Graves, 2013). Hal yang sama juga terjadi di Indonesia dengan peluncuran Cekfakta.com pada 2018 ini dan tersertifikasinya empat media daring Indonesia sebagai pengecek fakta oleh IFCN. Artinya, aktivitas pemeriksaan fakta oleh berbagai media meningkat seiring dengan meningkatnya ketegangan politik di ruang publik.
Berpijak pada tiga asumsi di atas, paparan dalam tulisan ini hendak menelaah bagaimana jurnalisme pemeriksa fakta sebagai manifestasi organisasi hipermedia. Secara lebih spesifik, tulisan ini hendak mengelaboraasi dua aras penting dalam perkembangan jurnalisme pemeriksa fakta hari ini. Pertama, tulisan ini bermaksud mengelaborasi konsep jurnalisme pemeriksa fakta dalam ruang lingkup kajian jurnalisme digital. Kedua, tulisan ini hendak mendedah secara lebih jauh model organisasi hipermedia yang dibangun dalam jurnalisme pemeriksa faktayang dibangun dengan kolaborasi antara jurnalis dengan media digital untuk memverifikasi informasi. Tujuan ini dicapai dengan melakukan studi literatur dengan mendedah sejumlah konsep untuk memberikan pondasi konseptual yang relevan. Limitasi penelitian ditetapkan pada wilayah ruang lingkup dimana sudut pandang yang digunakan di sini hanya berkaitan dengan fact-checking yang muncul dan dipergunakan dalam ranah jurnalisme saja.

\section{Metode}

Elaborasi dari fakta Fact-Checking Journalism dalam tulisan ini bermaksud memberikan gambaran komprehensif mengenai fenomena jurnalisme pemeriksa sebagai salah satu fenomena baru dalam ekosistem jurnalisme digital. Penjelasan dalam tulisan ini menggunakan studi literatur dengan memanfaatkan konsepkonsep kunci yang muncul dalam jurnal bereputasi nasional maupun internasional, guna menjelaskan secara konseptula bagaimana jurnalisme pemeriksa fakta berkembang sebagai kolaborasi berbagai elemen jurnalisme, antara manusia dengan mesin, dalam konteks organisasi hipermedia. 
Analisis Dan Pembahasan

\section{Jurnalisme Pemeriksaan Fakta sebagai Genre Jurnalisme Digital}

Fact-Checking (pemeriksaan fakta) bukan isu baru dalam perkembangan jurnalisme. Pada dasarnya, setiap proses jurnalisme membutuhkan pemeriksaan faktakarena prinsip dasar jurnalisme sendiri adalah faktualitas dan verifikasi. Terdapat sejumlah jejak historis titik tolak perkembangan jurnalisme pemeriksa fakta (fact-checking journalism). Praktik jurnalisme pemeriksa fakta awalnya muncul dalam fenomena "jurnalisme contong" ("muckracking journalism") untuk mengulas pemberitaan-pemberitaan kontroversial dengan menggunakan laporan investigasi (Amazeen, 2017). Sumber lain menyebutkan bahwa praktik jurnalisme ini mulai berkembang sejak era Ad-Watch Advertising (Graves, 2016; Amazeen, 2017) yang mengaburkan wilayah jurnalisme dengan kampanye politik. Dua jejak historis ini sama-sama memberikan gambaran mengenai proses pengecekan fakta yang melalui proses verifikasi berbagai data dan sumber informasi.

Pengecekan fakta dan verifikasi data lebih kompleks dilakukan sejak berkembangnya jurnalisme digital. Banyaknya data yang tersebar dan bisa diolah dalam media digital acapkali membuat informasi menjadi bias. Akan tetapi, pada prinsipnya, setiap aktivitas pemeriksaan fakta yang dilakukan berpegang pada nilai-nilai jurnlisme yang bertujuan memberikan informasi yang akurat kepada masyarakat (Gans, 2003; Gaves, et.al, 2016). Kompleksitas pemeriksaan fakta pada jurnalisme digital ini dipengaruhi oleh sejumlah faktor (Graves, 2016). Pertama, terjadi perubahan standar dan praktik jurnalisme dengan kehadiran media digital. Secara prinsip, jurnalisme tidak mengalami perubahan, tapi metode yang ditempuh untuk mengahasilkan nilai yang sama mengalami inovasi. Kedua, transformasi teknologi mengurangi peran gatekeeper dalam media baru. Dinamika ruang redaksi tidak lagi berlapis-lapis sebagaimana jurnalisme tradisional. Ruang digital memiliki peluang terbangunnyaa sistem media yang lebih efektif dan efisien dalam menjalankan kebijakan redaksional. Ketiga, ruang perdebatan publik dalam digital menjadi terfragmentasi. Interaktivitas membuat keterlibatan pengguna tidak selalu ber-tumpu pada ruang redaksi, tapi menyebar pada ruang-ruang diskusi yang lainnya.

Secara konseptual, tidak ada pemahaman yang seragam mengenai konsep jurnalisme digital sebagai pintu gerbang untuk memahami jurnalisme pemeriksa fakta. Konsep atas jurnalisme digital acapkali disamakan dengan jurnalisme daring (online journalism), jurnalisme konvergensi, atau jurnalisme multimedia. Konsep-konsep ini merujuk pada penggunaan media digital dalam proses produksi, distribusi, dan konsumsi informasi yang bertujuan untuk meningkatkan literasi informasi dan teknologi masyarakat (Kawamoto, 2003). Definisi ini lebih menekankan peran jurnalisme dalam demokrasi dan bagaimana teknologi menjadi daya dukung atas hal tersebut, baik dalam konteks kinerja jurnalis, ruang redaksi, dan distribusi berita. Secara lebih lanjut, pandangan ini mengamini bahwa media digital memberikan pengaruh pada perkembangan jurnalisme (Pavlik, 2008). Pertama, teknologi mempengaruhi produksi dan distribusi informasi dalam pemberitaan (Pavlik, 2000; Adzkia, 2015; Lewis \&Westlund, 2016). Kedua, jurnalisme merupakan bagian dari masyarakat yang dibentuk secara sosial maupun material oleh cukup banyak akun (baik produsen maupun user) dalam media digital (Deuze, 2007; Lewis \& Westlund, 2016). Namun, mendefinisikan 
jurnalisme digital dan mengelaborasi konsep jurnalisme peme-riksa faktatidak hanya sekadar melihat bagaimana pengaruh teknologi terhadap jurnalisme. Sudut pandang yang holistik dalam melihat pengaruh teknologi pada jurnalisme melibatkan cukup banyak aras yang masih akan terus berkembang seiring dengan perkembangan media digital. Sampai titik ini, pemetaan atas perkembangan media digital atas jurnalisme memberikan konsep-konsep baru yang masih harus digali, seperti sistem manajemen media digital, jurnalisme komputasi, perkembangan algoritma pada jurnalisme, analisis user sebagai audiens, jurnalisme data, artificial intelligence journalism, dan konsep-konsep lainnya (Lewis \& Westlund, 2016; Coddington, 2015; Albaran, 2016; Deuze, 2007). Kondisi ini menunjukkan pengaruh media digital terhadap jurnalisme hendaknya tidak dilihat dari aspek artefak fisik semata, tapi pada sejauh mana transformasi nilai dari jurnalisme itu sendiri pada masyarakat.

Perkembangan media digital merupakan keniscayaan pada era masyarakat jaringan. Infomasi menjadi komoditas utama yang membentuk simpul-simpul dalam masyarakat. Peran jurnalisme tidak hanya sekadar berada pada aras normatif untuk menginfor-masikan, mendidik, menghibur, dan watchdog. Peran ini bertambah dengan kebutuhan masyarakat atas informasi dan berjejaring. Jurnalisme memiliki empat peran penting dalam periode masyarakat jaringan saat ini (Bradshaw, 2017), yaitu menyuarakan yang tidak bersuara; menemukan hal-hal yang tersembunyi; menghubungkan komunitas-komunitas dalam masyarakat; serta menyanggah berita bohong dan melakukan verifikasi informasi. Peran jurnalisme pemeriksa fakta dalam hal ini adalah melakukan verifikasi informasi dan memberikan informasi yang tepat untuk mencegah misinformasi.

Pemeriksaan fakta dalam praktik jurnalisme digital ini dilakukan dengan metode naratif sebagaimana jurnalisme digital pada umumnya. Secara umum, karakter jurnalisme pemeriksa fakta sama dengan jurnalisme digital secara umum, yaitu hipertekstualitas, interaktivitas, nonlinearitas, multimedia, konvergensi, dan personal (Kawamoto, 2003; Pavlik 2008). Namun, pada jurnalisme pemeriksa fakta, hal yang paling menonjol adalah "reported speech" daripada "reporter gets a quote right" (Amazeen, 2017). Sudut pandang media melalui narasi reporter menjadi tumpuan utama. Tujuan utama dari jurnalisme pemeriksa fakta adalah mendidik publik, meningkatkan perilaku politik, dan meningkatkan kualitas jurnalisme (Amazeen, 2017). Oleh karenanya, membangun perspektif melalui narasi yang akurat lebih penting daripada mendapatkan narasumber utama yang bias. Narasi berita tidak mengandalkan kutipan dari narasumber, tapi memaksimalkan semua sumber berita yang bisa didapatkan dari berbagai konten digital. Inilah yang membuat jurnalisme pemeriksa fakta memiliki titik tumpu yang berbeda dengan jurnalisme digital secara umum.

Secara umum, isu dan organisasi yang bergerak sebagai pemeriksa fakta terbagi dalam tiga kategori (Brandtzaeg dan Folstad, 2017), yaitu isu politik dan isu publik; rumor dan hoax; serta topik khusus, kontroversi, konflik, dan kejadian dalam ruang lingkup terbatas. Jurnalisme pemeriksa fakta akan menampilkan narasi isu-isu tersebut dengan membangun narasi yang komprehensif. Umumnya, yang dilakukan adalah dengan menampilkan sumber utama yang menjadi dasar klaim dan tautan yang menjadi acuan untuk melakukan verifikasi. Tautan dan narasi inilah yang menjadi dasar untuk 
memberikan justifikasi bahwa jurnalisme pemeriksa fakta dibangun dengan menerobos batasan organisasi media dengan membangun organisasi hipermedia.

Dinamika redaksional organisasi media umumnya digambarkan dengan relasi yang terbangun antarjurnalis dan berbagai elemen organisasi media lainnya. Organisasi media menunjukkan pola-pola yang terbangun antara jurnalis, struktur dalam media, serta sistem sosial masyarakat (McQuails,2013:6). Pada konteks jurnalisme digital, organisasi media tidak hanya berkaitan dengan relasi manusia dengan manusia, tapi juga antara manusia dengan mesin. Paling tidak, terdapat empat aspek yang bisa menjadi penjelasan bagaimana relasi antara jurnalis sebagai manusia dan sumbersumber media digital sebagai mesin dalam konteks ekosistem jurnalisme digital (Lewis \& Westlund, 2016), yaitu (1) human centric journalism; (2) technologysupported journalism; (3) technology infused journalism; dan (4) technology oriented journalism. Keempat aspek tersebut menjadi ilustrasi bagaimana proses produksi dan distribusi informasi dengan menempatkan teknologi sebagai faktor dependensi pada organisasi media. Human centric journalism menempatkan manusia sebagai aktor utama dan media digital sebagai alat, tapi tidak secara dominan mempengaruhi kinerja jurnalis. Technology-supported journalism menempatkan teknologi menjadi faktor yang mendukung kinerja jurnalis. Penggunaan teknologi dalam konteks ini adalah pilihanpilihan ramah penguna dalam mendukung kinerja jurnalis. Jurnalisme syarat teknologi (technology-infused journalism), di sisi lain, menempatkan jurnalis dalam melembagakan teknologi sebagai bagian kinerja mereka dalam produksi dan distribusi informasi. Tanpa teknologi dan media digital maka jurnalis tidak bisa melakukan aktivitas jurnalismenya. Jurna- lisme berorientasi pada teknologi (technology-oriented journalism) bahwa media digital tidak hanya sekadar menjadi medium yang mendukung dan memfasilitasi jurnalisme, tapi media digital itu sendiri menjadi penentu proses jurnalisme. Penggunaan algoritma yang spesifik serta sistem mesin-mampu-belajar (machine-learning-system) menjadi tumpuan dari aktivitas jurnalisme.

Jurnalisme pemeriksa fakta lebih dominan mengembangkan bentuk ketiga (technology infused journalism) dan bentuk keempat (technology oriented journalism) pada konteks relasi manusia dengan mesin. Pengembangan ini sesuai tujuan jurnalisme pemeriksa fakta,untuk memberikan informasi yang relevan dan mengurangi klaim palsu atau ketidakakuratan yang disebarkan oleh pihakpihak tertentu, terutama politisi (Amazeen, 2017; Thorson, 2013; Coddington, 2014; Uscinski, 2015; ). Pengurangan atas klaim palsu ini dilakukan dengan memberikan dasar bukti melalui tautan pada narasi yang bisa jadi didapatkan dari organisasi media yang lain atau aplikasi pemeriksa data. Upaya yang dilakukan untuk meluruskan informasi yang keliru ditempuh dengan cara yang serupa, yaitu menautkan informasi yang benar melalui tautan atau memberikan rekomendasi bacaan yang sepadan melalui hiperlink, infografis, video, gambar, dan elemen konten digital lainnya. Pada dua konteks inilah, peran mesin-mesin digital menjadi signifikan dalam mempengaruhi kinerja dari jurnalis.

\section{Konsep Organisasi Hipermedia}

Pada dasarnya, konsep hipermedia, merujuk pada konsep suprastruktur yang menggabungkan perangkat keras yang cepat dan berkapasitas tinggi dengan perangkat lunak yang memungkinkan orang untuk mengirimkan informasi, 
interaksi, dan menggunakan data secara maksimal. Konsep hipermedia dibangun dari dua aras, multimedia dan hiperteks (Burton, et.al., 1995). Dua aras ini berakar pada kajian tentang media dan kajian tentang ilmu komputer. Oleh karenanya, hipermedia tidak hanya terdiri dari teks semata, tapi juga menggabungkan suara, video, grafik, dan berbagai aspek yang lazimnya muncul dalam multimedia. Secara fungsional, sistem hipermedia menyediakan aspek-aspek pendukung untuk keterhubungan teks dan interaktivitas (Isakowitz, 1992). Pertama, sistem hipermedia bersifat anotasi dimana user memiliki peluang untuk melakukan aktivitas yang berhubungan dengan teks. Kedua, navigasi. Hal ini berkaitan dengan peluang bagi user untuk menjelajahi hyperdocuments melalui tautan dari link yang muncul. Ketiga, struktur. Tautan dalam sistem hipermedia dapat digunakan untuk membuat berbagai unit tergabung secara asosiatif. Ini termasuk referensi yang sifatnya hierarkis dan terhubung melalui substruktur seperti membuat kategorisasi dokumen atau pengelompokkan tertentu.

Secara keseluruhan, organisasi hipermedia merujuk pada perpaduan berbagai perangkat media yang terkoordinasi, runut, non-linear dan interaktif (Nelson, 1981; Burton, et.al., 1995). Akses atas informasi dan konten media ditentukan oleh user yang menjadi pengendali utamanya. Ruang kontrol berada pada aras individu. Pada praktik jurnalisme pemeriksa fakta, hal ini ditemukan pada praktik jurnalis dalam mengelaborasi informasi. Sementara itu, konsep interaktivitas merujuk pada relasi yang dibangun antara konten dengan konten dan konten dengan user. Aspek hipertekstualitas organisasi hipermedia memungkinkan dihasilkannya konten oleh pengguna (user-generatedcontent).
Prinsip hipermedia dibangun dari keinginan membangun sistem melalui perangkat digital untuk mengembangkan dan memfasilitasi kecerdasan manusia (Nelson, 1981). Oleh karenanya, pada konteks hipermedia, media digital diposisikan sebagai medium untuk mendiseminasi pengetahuan, membangun relasi antara grup ataupun orang per orang (individual), menyasar target yang sesuai, dan membuat mereka yang terhubung dalam ruang lingkup tersebut menjadi lebih humanis (Carpenter \& Lertpratchya, 2016). Ide dan literatur dalam media digital berfungsi sebagai "system of interconnected writings" (Nelson, 1981) sehingga semua elemen dalam dunia digital sebenarnya terhubung untuk membuat berbagai hal lebih sesuai. Organisasi atas informasi membuat berbagai aspek menjadi lebih jernih dan terhubung.

Untuk mengembangkan dan membangun kecerdasan manusia, organisasi hipermedia dibangun dengan mempertimbangkan persoalan paling mendasar sebagai materi pembuatan sistem. Jika persoalan dalam masyarakat hari ini adalah hoax dan misinformasi, maka organisasi hipermedia dibangun untuk memberikan faktualitas informasi dan kejelasan data. Fungsi dasar dari suatu organisasi hipermedia dibangun dengan mempertimbangkan tiga elemen (Isakowitz, 1992), yaitu perspektif tugas, perspektif pengetahuan, dan perspektif integrasi. Kualifikasi dari masing-masing elemen tersebut menjadi penilaian atas sistem hipermedia yang dibangun. Jenis tugas dari sistem menjadi dasar penentuan pengetahuan yang dibutuhan dan pada gilirannya menjadi penentu sistem integrasi yang dibutuhkan. Hal ini pun berlaku sebaliknya.

Pertama, elemen tugas (task perspective). Komponen pertama yang dibutuhkan untuk melihat organisasi hipermedia adalah tugas yang akan 
dilekatkan kepadanya. Sebagai jaringan yang akan memproses dan mengelola informasi, tugas organisasi hipermedia perlu mempertimbangan berbagai persyaratan serta kapasitas yang akan dibangun. Komponen tugas ini paling tidak dibangun dengan mempertimbangkan dua aspek, yaitu ketidakpastian (uncertainty) dan ketidakcocokan (equivocality) (Daft \& Lengel, 1986). Ketidakpastian adalah perbedaan jumlah informasi yang diperlukan untuk melakukan tugas dan jumlah informasi yang dimiliki oleh organisasi (Daft \& Lengel, 1986). Semakin banyak informasi yang dimiliki oleh organisasi, maka ketidakpastian akan semakin direduksi. Sementara itu konsep ekuivokalitas berkaitan dengan pertentangan atas interpretasi dalam organisasi (Weick, 1979). Asumsinya, tingginya ketidakcocokan dalam organisasi menunjukkan kebingungan dan kurangnya pemahaman tentang organisasi. Secara fungsional, tugas dari hipermedia adalah mereduksi ketidakpastian dan ketidakcocokan dalam sistem.

Komponen yang kedua adalah perspektif pengetahuan. Persoalan utama dalam suatu organisasi adalan pengelolaan untuk pengetahuan organisasi yang sangat luas (Isakowitz, 1992). Efisiensi organisasi dapat tercapai apabila organisasi dapat mengelola berbagai informasi yang masuk ke dalam organisasi melalui repositori atau ingatan organisasional (organizational memory). Hipermedia dibangun bukan bukan untuk menghapus informasi lama dan menggantikannya dengan informasi baru, tapi mengelola semua informasi tersebut dan menyediakannya pada saat dibutuhkan. Pada prinsipnya, representasi hipermedia terwakili oleh ingatan organisasional ini, riilnya adalah bagaimana informasi-informasi terhubung melalui tautan yang efektif sehingga membentuk pengetahuan yang menyeluruh.
Komponen ketiga adalah perspektif integrasi. Integrasi dalam hipermedia berkaitan dengan bagaimana mengintegrasikan sistem ini dengan aplikasi lain sebagai bentuk adopsi hipermedia (Meyrowitz dalam Isakowitz, 1992). Bagian ini yang paling menantang dalam mengembangkan hipermedia karena kebanyakan sistem hipermedia dibangun untuk menjadi aplikasi yang mandiri. Dua hal yang menjadi perhatian dalam konteks integrasi ini adalah arsitektur dasar dari hipermedia dan teknik pertukaran informasi. Kondisi ini mendorong kreator hipermedia untuk menciptakan sistem hipermedia yang inovatif dengan kemampuan komunikasi yang dinamis antara sistem hipermedia dengan aplikasi lain pada suatu ruang lingkup organisasi.

Ketiga elemen pembangun hipermedia, yaitu tugas, pengetahuan, dan integrasi akan menjadi dasar untuk melihat bagaimana jurnalisme pemeriksa faktabekerja. Jika kembali kepada fungsi dasar dari organisasi hipermedia, dengan mengandalkan ketiga elemen tersebut, hendaknya jurnalisme pemeriksa data dapat memenuhi fungsi anotasi, navigasi, dan struktur (Isakowitz, 1992). Pertama, jurnalisme pemeriksa fakta memungkinkan semua pengguna terhubung dan melakukan aktivitas pribadi tanpa melakukan perubahan terhadap laman yang tertaut kepadanya. Kedua, jurnalisme pemeriksa faktamemberikan ruang jelajah kepada user melalui sistem navigasi yang terhubung kepadanya. Ketiga, jurnalisme pemeriksa faktamembentuk asosiasi dan struktur dari unit-unit yang terhubung melalui referensi silang, hierarki, dan suprastruktur melalui berbagai tautan. 


\section{Organisasi Hipermedia pada jurnalisme pemeriksa fakta}

jurnalisme pemeriksa fakta merupakan organisasi hipermedia yang terbentuk di ranah jurnalisme. Konteks ini meletakkan jurnalisme pemeriksa fakta tidak hanya sebagai aktivitas jurnalisme, tapi juga menjadi manifestasi organisasi informasi yang terbentuk dalam media digital. Kondisi ini merujuk pada fenomena jurnalisme pemeriksa fakta yang menyediakan konten klaim fakta beserta bukti dan penyanggah dalam platform digital. Secara umum, pola kerja jurnalisme pemeriksa faktabisa dipilah ke dalam tiga bagian, yaitu menemukan klaim yang membutuhkan pengecekan, menemukan fakta yang menjadi bukti, dan melakukan evaluasi atas klaim awal (Ireton \& Posetti, 2018: 89).

Proses pada jurnalisme pemeriksa fakta mempergunakan potensi media digital dalam mengelola informasi. Keunggulan media digital dibandingkan dengan media tradisional adalah kemampuan jurnalisme dalam melakukan hipertekstualitas (Pavlik, 2008; Howard, 2002). Pertama, secara terstruktur, media digital didukung dengan jaringan satelit, stasiun relai, basis data yang relevan dalam pengumpulan dan penyampaian informasi kepada publik atau pengguna secara keseluruhan. Kedua, dari sisi kecepatan dan jumlah konten, kemampuan media digital jauh mengungguli media media tradisional. Ketiga, pada konteks interaksi, media digital memungkinkan terjadinya interaksi daring dan luring. Sirkulasi simbol dan makna sosial, dekomposisi dan rekomposisi pesan, dan peningkatan simbol sosial secara signifikan dilakukan dengan cara-cara yang diadaptasi dan disesuaikan dengan cara komunikasi analog. Hipertekstualitas inilah yang menjadi dasar bagaimana jurnalisme pemeriksa faktabekerja. Secara lebih lanjut, pola umum yang terbangun dalam JPF adalah sebagai berikut:

\section{Gambar 1. JPF dalam}

\section{Organisasi Hipermedia}

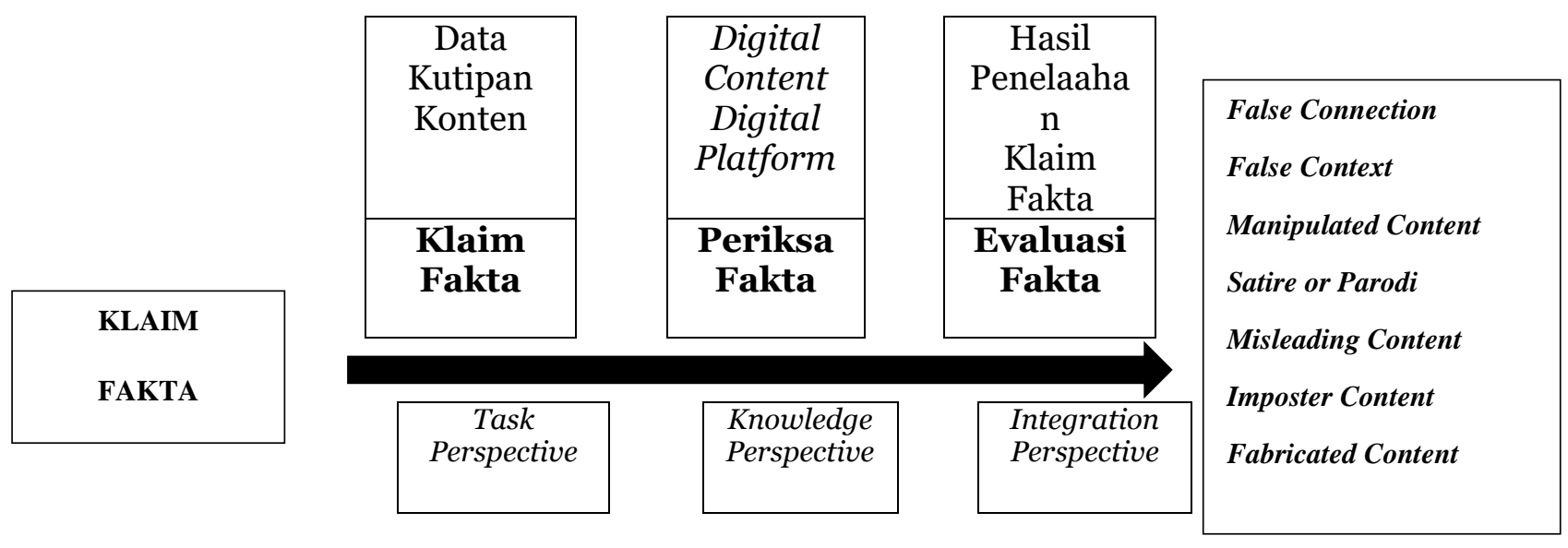


Memahami jurnalisme pemeriksa fakta sebagai organisasi hipermedia dibangun dengan tiga tingkatan. Pertama, melihat tugas dan fungsi pokok dari jurnalisme pencari fakta. Kedua, melihat tujuan yang hendak didapatkan dari ekosistem digital yang dibangun pada JPF. Ketiga, melihat hasil akhir dari proses jurnalistik yang terjadi pada jurnalisme pencari fakta.

Tugas dan fungsi pokok jurnalisme pencari fakta adalah melakukan pemeriksaan fakta melalui proses verifikasi berbagai data dan sumber informasi. Pemeriksaan fakta dan verifikasi data ini dilakukan dengan berpegang pada nilainilai jurnalisme yang bertujuan memberikan informasi yang akurat kepada masyarakat (Graves, et.al, 2016; Gans, 2003). Pada prinsipnya, task perspective dalam jurnalisme pemeriksa fakta dibangun dari tugas pokok jurnalisme pada umumnya. Perbedaannya terletak pada modal dasar. Pada jurnalisme pemeriksa fakta, modal berasal dari klaim pihakpihak tertentu atas suatu fenomena. Modal dasar ini menjadi titik awal pengecekan fakta yang akan dilakukan oleh jurnalis atau dalam jurnalisme disebut sebagai nara-sumber utama.

Sumber utama dalam media digital berasal dari unggahan pertama yang masuk dalam dunia digital. Sumber ini bisa berasal dari mana saja di wilayah konten digital. Unggahan ini bisa berasal dari laman berita tertentu, bisa pula berasal dari media sosial. Masifnya media digital membuat jurnalis harus berinteraksi dengan banyak data untuk mencari mana yang menjadi sumber asli dari suatu klaim fakta. Pada konteks inilah relasi manusia dan mesin, jurnalis dan aplikasi media digital, dibutuhkan. Sejumlah aplikasi pelacak saat ini dimanfaatkan jurnalis untuk mencari sumber awal dari suatu unggahan, misalnya, Crowdtangle yang dikembangkan oleh Facebook.

Bagian pertama jurnalisme pemeriksa faktaadalah memberikan kepastian dan kecocokan kepada pengguna bahwa tugas pencarian informasi yang benar ini yang dilakukan. Pada praktik pencarian sumber atas klaim fakta yang dilakukan jurnalis, platform jurnalisme pemeriksa faktaakan melibatkan publik untuk melihat sumber asli dengan memberikan tautan. Tautan ini bisa berupa aplikasi yang membantu masyarakat untuk mengecek atau tautan halaman dimana informasi tersebut pertama kali muncul.

Mencari sumber asal bukan menjadi tujuan akhir jurnalisme pemeriksa fakta. Tujuan utama jurnalisme pemeriksa fakta adalah mendidik publik, mengingkatkan perilaku politik, dan meningkatkan kualitas jurnalisme (Amazeen, 2017). Oleh karenanya, alih-alih memberikan penilaian asal fakta dari mana, jurnalisme pencari fakta juga membantu masyarakat untuk memahami letak distorsi dan konteks permasalahan secara keseluruhan. Inilah yang menjadi inti bagian kedua jurnalisme pemeriksa fakta.

Knowledge perspective dalam jurnalisme pemeriksa fakta dibangun dengan memberikan keluasan pengetahuan kepada masyarakat. Bangunan pengetahuan dalam ruang hipermedia jurnalisme pemeriksa fakta merupakan unjuk kebolehan penggalian sumber sebanyakbanyaknya oleh jurnalis guna membantu masyarakat membangun kesimpulan. Sebagai contoh, jika klaim fakta yang ditemukan ternyata misinformasi atau hoax, maka jurnalis memiliki kewajiban untuk memberikan bukti bahwa informasi tersebut hoax serta menunjukkan informasi yang tepat. Pada praktiknya, proses untuk menilai ini tidak berasal dari simpulan informasi subjektif yang diberikan oleh jurnalis, tapi tautan yang 
akan membuat masyarakat bergerak untuk menilai apakah data dan informasi yang ia baca sudah tepat atau belum.

Interaktivitas yang dibangun oleh jurnalis dengan masyarakat di sini tidak hanya ditunjukkan dari konten media yang diberikan oleh jurnalis kepada masyarakat, tapi juga tautan dari konten ke konten sebagai bagian dari verifikasi data. Klaim data atas kemiskinan, misalnya, ditemukan bahwa data kemiskinan yang diklaim oleh politisi tertentu rupanya misinformasi. Pada jurnalisme digital umumnya, jurnalis akan menyajikan data dari politisi tertentu yang hoax dan data dari institusi yang memiliki legitimasi sebagai penyandingnya. Di sinilah, prinsip liputan dua sisi (cover both sides) cditerapkan. Namum, dalam jurnalisme pemeriksa fakta, jurnalis tidak hanya memberikan sajian data yang menunjukkan data yang hoax dan data yang benar, namun jurnalis juga memberikan tautan pada laman tertentu yang bisa memberikan data sahih terkait data kemiskinan, misalnya, tautan laman Badan Pusat Statistik. Pada tautan ini, masyarakat yang membaca berita tidak hanya diajak untuk memahami narasi yang hendak diketengahkan oleh jurnalis, tapi juga membaca konteks permasalahan secara keseluruhan guna mendapatkan narasi utuh atas fenomena.

Keterlibatan masyarakat dalam membaca keseluruhan informasi melalui sumber-sumber asli ini merupakan poin kunci yang membedakan antara jurnalisme pemeriksa data dengan jurnalisme digital pada umumnya. Dalam konsep jurnalisme digital secara umum, hipertekstualitas dan hiperlink dibangun oleh platform jurnalisme digital dengan memberikan tautan pada masing-masing laman berita sehingga penggunaakan mengikuti tautan tersebut untuk membaca narasi berita secara keseluruhan. Narasi ini masih bersumber pada satu organisasi media dan menghubungkan frame demi frame yang dibangun oleh media melalui unggahannya. Hal ini berbeda dengan praktik yang ditemukan dalam JPF. Hipertekstualitas dan hiperlink dihubungkan dengan banyak data yang tersebar, baik dari dalam organisasi media maupun dari luar organisasi media. Batasan-batasan antara internal dan eksternal itu luruh dalam satu laman yang menyajikan elaborasi fakta dan data secara keseluruhan. Jurnalis bertindak sebagai aktor yang menyusun simpul informasi melalui tautan yang dia buat dalam narasinya.

Bagian terakhir kerangka kerja jurnalisme pemeriksa fakta adalah integrasi. Pada wilayah teknis, integrasi dipahami sebagai adopsi berbagai sistem yang terhubung dalam sistem hipermedia (Meyrowitz dalam Isakowitz, 1992). Pada konteks implementasi jurnalisme pemeriksa fakta, integrasi ini berarti evaluasi atau penilaian akhir atas klaim fakta yang disajikan sejak awal. Bagian ini menampilkan kesimpulan yang menunjukkan apakah klaim fakta yang diperiksa sejak awal benar atau tidak. Mengacu pada rekomendasi First Draft (2016) yang mengadaptasi proses pemeriksaan fakta yang dilakukan oleh Google News Initiative, kesimpulan atas fakta yang diperiksa oleh media bisa disimpulkan dalam tujuh kategori, yaitu: kesalahan keterhubungan antara judul, konten, dan elemen pendukung informasi (false connection); kesalahan konteks informasi yang disajikan (false context); informasi mengalami distorsi dan manipulasi (manipulated content); konten bersifat fiksional karena memuat satire atau sindiran tertentu (satire or parodi); kesalahan penggunan informasi untuk keuntungan parsial atau individual (misleading content); sumber asli merupakan tiruan atau reduplikasi dari sumber lain (imposter content); dan tipu muslihat (fabricated content). 
Integrasi sebagai simpulan akhir dari pemeriksaan fakta ini setiap media memiliki ciri khas masing-masing. Rekomendasi yang ditawarkan oleh Google News Initiative dan First Draft merupakan konsep yang paling kompleks dan detail untuk menunjukkan integrasi data, fakta, dan narasi yang dibangun. Akan tetapi, pada praktiknya kebanyakan jurnalisme pemeriksa faktamenggunakan simpulansimpulan yang lebih sederhana seperti hoax atau fakta (Kompas.com); informasi benar dan informasi salah (Tirto.id); benar, sebagian benar, tidak terbukti, sesat, dan keliru (Tempo.co). Media memberikan ruang kepada masyarakat untuk turut menyimpulkan karena dalam prosesnya masyarakat juga terlibat untuk melakukan verifikasi.

\section{Penutup}

Jurnalisme pemeriksaan fakta (fact-checking journalism) (JPF) merupakan tren baru dalam jurnalisme digital. Tren ini berkembang seiring dengan terjadinya ledakan informasi di ruang publik yang membuat hoax, fake news, dan misinformasi ditemukan dalam berbagai konten media. Tren baru ini menghadirkan diskusi konseptual sebagaimana terangkum dalam tulisan ini. Pertama, JPF tidak hanya merupakan tren yang sedang berkembang dalam ekosistem jurnalisme digital. Namun, tren ini juga memunculkan konsep dan genre baru dalam kajian jurnalisme digital. Kedua, fenomena jurnalisme pemerikasa fakta yang berkembang di Indonesia merupakan manifestasi dari organisasi hipermedia. JPF hadir untuk memberikan informasi yang akurat sekaligus melibatkan masyarakat dalam proses verifikasi informasi yang berlangsung. Sebagai genre baru dalam jurnalisme digital, JPF mengkolaborasikan manusia dan mesin dalam praktik jurnalistik. Jurnalis merupakan kreator ekosistem yang bertugas menciptakan narasi, mengikat simpul informasi, dan membangun navigasi bagi user. Pengguna (user) merupakan pembaca, pengakses, sekaligus penilai yang akan membantu media untuk menyimpulkan kesahihan suatu informasi. Sementara aplikasi digital menjadi ekosistem yang membuat berbagai simpul informasi ini terhubung serta menjembatani pemahaman yang dibangun antara jurnalis dengan publik. Dengan demikian, pada konteks komunikasi kontemporer, ekosistem JPF merupakan manifestasi atas organisasi hipermedia. Sistem media dibangun tidak hanya sebagai platform informasi, edukasi, dan watchdog, namun juga mengembangkan dan memfasilitasi kecerdasan manusia. Kolaborasi menjadi kata kunci yang penting disini karena semua elemen terlibat untuk mengembangkan ekosistem jurnalisme digital. 


\section{DAFTAR PUSTAKA}

Adzkia, Aghnia R.S. (2015). Praktik Multimedia dalam Jurnalisme Online di Indonesia: Kajian Praktik Wartawan Multimedia di cnnindonesia.com, rappler.com, dan tribunnews.com.Jurnal Komunikasi, Volume 10, Nomor 1, Oktober 2015.

Albarran, Alan B. (2016). Management of Electronic and Digital Media, 6th Edition. Austalia, United States: Cengage Learning. Hlm 11-19.

Amazeen, Michelle A. (2017). Journalictic Interventions: The Structural Factors Affecting The Global Emergence of Fact-Checking. Journalism, 2017, 117.

Bradshaw, Paul. (2017). The Online Journalism Handbook: Skills to Survibe and Thrive in The DIgital Age, 2nd Edition. London: Routledge.

$<<$ https://www.routledge.com/TheOnline-Journalism-Handbook-

Skills-to-Survive-and-Thrive-in-theDigital/Bradshaw/p/book/97811387 91565>>

Brandtzaeg, P.B., et.al. (2015). Emerging Journalistic Verification Practices Concerning Social Media. Journalism Practice, 2015.

Brandtzaeg, P. B.,Følstad, A. (2017). Trust and Distrust in Online Fact-Checking Services. Communications of the ACM 60 (9): 65-71.

Burton, J.K., et.al. (1995). Hypermedia Concepts and Research: An Overview. Computers in Human Behavior, Vol.11, No.3-4, pp 345369.

Carpenter, Serena., Lertpratchya, Alisa P. (2016). Social Media Communicator Roles: A Scale. Social Media and Society, 2(1), 205630511663277. doi:10.1177/2056305116632778 .
Coddington, M., et.al. (2014). FactChecking the Campaign: How Political Reporters Use Twitter to Set the Record Straight (or Not). The International Journal of Press/Politics, 2014, Vol 19(4), 391409.

Coddington, Mark. (2015). Clarifying Journalism's Quantitative Turn. Digital Journalism, 3(3), 331-348.

Daft, Richard L., Lengel, Robert H. (1986). Organizational Information Requirements, Media Richness, and Structural Design. Management Science, Vol. 32, No. 5, Organization Design. (May, 1986), pp. 554-571.

Deuze, Mark. (2007). Media Work. Cambridge, Malden: Polity Press.

Franklin, B., Eldridge II, S.A. (ed.) (2017). The Routledge Companion to Digital Journalism Studies, London, New York: Routledge.

Freeom House. (2017). Freedom On The Net 2017: Manipulaing Social Media to Undermine Democracy, Washington, New YOrk: Freeom House.

Gans, H.J. (2003). Democracy and The News. New York: Oxford University Press.

Graves, Lucas. (2013). Deciding What's True: Fact-Checking Journalism and the New Ecology of News. Dissertation. Columbia University.

Graves, Lucas, et.al. (2016).
Understanding Innovations in
Journalistic Practice: A Field
Experiment Examining Motivations
for Fact Checking. Journal of
Communication, 66(2016), 102-138. 
Ireton, Cherilyn., Posetti, Julie. (2018). Journalism, Fake News, and Disinformation: Handbook for Journalism Education and Training . Prancis: UNESCO.

Isakowitz, Tomas. (1992). Hypermedia, Information Systems, and Organization: A Research Agenda. Working Paper Series. New York: Center for Digital Economy Research Stern School of Business.

Kawamoto, Kevin (ed.). (2003). Digital Journalism: Emerging Media and the Changing Horizons of Journalism. Landham, New York, Oxford: Rowman and Littlefield Publishers, Inc.

Kovach, B., Rosentiel, T. (2003). Sembilan Elemen Jurnalisme: Apa yang Seharusnya Dilakukan Wartawan dan Diketahui Publik. Jakarta: Yayasan Pantau.

Lecheler, Sophie., Kruikemeier Sanne. (2016). Re-evaluating Journalistic Routines in a Digital Age: A Review of Research on The Use of Online Sources. New Media and Society, 2016, Vol.18(1), 156-171.

Lewis, S.C., Westlund, Oscar. (2016). Mapping the Human-Machine Divide in Journalism. dalam Tamara Witschge, et.al. (ed). The Sage Handbook of DIgital Journalism. Los Angeles, London, New Delhi: Sage Publications.

McQuails, Denis. (2013). Journalism and Society. Singapore, Washington DC: Sage Publications.
Nelson, T.H. (1981). Literary Machines. Swarthmore, PA: Author.

Pavlik, J. (2000). The Impact of Technology on Journalism. Journalism Studies, 1(2), 229-237. DOI:10.1080/14616700050028226

Pavlik, John V. (2008). Media in The Digital Age. New York: Columbia University Press.

Thorson, E. (2013).The Consequences of Misinformation and Fact-checking for Citizens, Politicians, and The Media. dalam The annual meeting of the Midwest Political Science Association, Chicago, IL, 11-14 April.

Schudson, M. (2001). The Objectivity Norm in American Journalism. Journalism, 2, pp 149-70.

Unesco. (2018). Journalism, Fake News, and Disinformation: Handbook for Journalism Education and Training . Perancis: UNESCO

Uscinski, Joseph E. (2015). The Epistemology of Fact Checking (Is Still Naive): Rejoinder to Amazeen. Critical Review: Journal of Politics and Society, 27:2, 1-10.

Weick, Karl. (1979). The Social Psychology of Organizing. New York: Newbery Award

Yudhapramesti, Pandan. (2015). Jurnalis dan Jurnalisme dalam Fenomena Kontemporer. Jurnal Komunikasi, Volume 10 , Nomor 1, Oktober 2015 